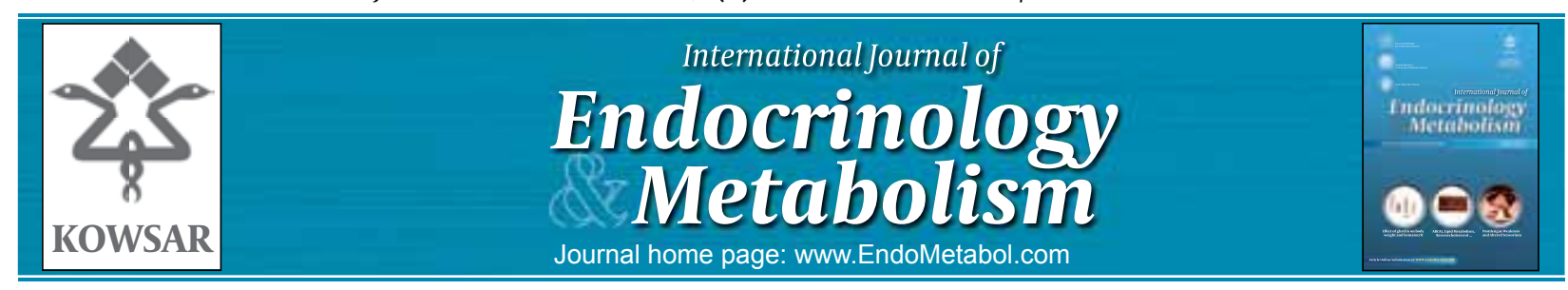

\title{
Distinct Effects of Metformin on Pdx-1 Before and After Birth
}

\author{
Bruno Doiron $^{1^{*}}$, Ralph A DeFronzo ${ }^{1}$ \\ ${ }^{1}$ Diabetes Division, University of Texas Health Science Center, San Antonio, Texas, USA
}

\begin{tabular}{l}
\hline A R T I C L E I N F O \\
\hline Article type: \\
Letter to Editor \\
\hline Article history: \\
Received: 20 Jan 2011 \\
Revised: 03 Feb 2011 \\
Accepted: 07 Feb 2011 \\
\hline Keywords: \\
Mice \\
Embryos \\
Pancreas \\
Pancreatic and Duodenal Home \\
obox1 Protein \\
Insulin \\
Metformin \\
\end{tabular}

\section{Dear Editor,}

In a recent article (Int J Endocrinol Metab 8:211-214, 2010), Hashemitabar et al. (1) have shown that intraperitoneal injection of metformin in pregnant mice induces an increase in the levels of Pdx-1 and insulin mRNA in neonatal mice but not in 19.5 embryonic fetuses. On the basis of these results, the authors concluded that metformin affects the regulatory region of the insulin gene only after birth. The transcriptional factor Pdx-1 is expressed in both endocrine and exocrine tissues and is essential for pancreatic development in the embryonic stage (2). Mice with knocked out Pdx-1 gene do not develop a pancreas; therefore, this deletion is lethal (3). However, after pancreatic development, Pdx-1 is expressed only in insulin-producing $\beta$ cells and somatostatin-producing $\delta$ cells (4). Pdx-1 transactivates the insulin gene in $\beta$ cells obtained from mature animals (5). However, the expression of the insulin gene is not regulated by Pdx-1 in the embryonic stage. Insulinexpressing cells are observed even in Pdx-1 homozygous

\footnotetext{
* Corresponding author: Bruno Doiron, Diabetes Division, University of Texas Health Science Center, San Antonio, Texas, USA. Tel: +1-2105670767, Fax:+1-2105676554,E-mail: doiron@uthscsa.edu

Please cite this paper as:

Doiron B, DeFronzo RA. Distinct Effects of Metformin on Pdx-1 Before and After Birth. Int J Endocrinol Metab. 2011; 9(2):356-7. DOI: 10.5812/kowsar.1726913X.2448

Copyright @ 2011 Kowsar M. P. Co. All rights reserved.

mutant mice (6). Metformin has 2 distinct effects on the levels of Pdx-1 protein. First, although metformin does not regulate Pdx-1 gene expression, it increases Pdx-1 protein levels after $24 \mathrm{~h}$ in isolated rat islets (7), suggesting that metformin has a post-transcriptional effect on Pdx-1 production. Second, metformin induces the translocation of Pdx-1 from the cytoplasm to the nucleus of MIN6 pancreatic cells and increases binding of Pdx-1 to the reporter gene construct that includes the promoter for the human proinsulin gene (7). Therefore, the ability of metformin to increase the expression levels of the insulin gene in mature pancreatic $\beta$ cells could be partly explained by the synergistic effect of the 2 above-mentioned mechanisms involved in the metformin-mediated regulation of Pdx-1 protein levels. This hypothesis is consistent with the findings of Hashemitabar et al., who have clearly shown that the main effect of metformin on Pdx-1 takes place after birth and that metformin does not interfere with the embryonic development of the pancreas.

\section{Financial Disclosure}

Neither Drs. Doiron and DeFronzo have any conflict of interests or financial disclosures as they relate to the present commentary. 


\section{References}

1. Hashemitabar M, Mehranjani MS, Momeni H, Bahramzadeh S, Negad Dehbashi F, Khorsandi L. The effects of metformin on Pdx1 and insulin gene expression in mouse embryonic and neonatal pancreas. Int J Endocrinol Metab. 2010;8(4):211-4

2. Guz Y, Montminy MR, Stein R, Leonard J, Gamer LW, Wright CV, et al. Expression of murine STF-1, a putative insulin gene transcription factor, in beta cells of pancreas, duodenal epithelium and pancreatic exocrine and endocrine progenitors during ontogeny. Development. 1995;121(1):11-8.

3. Offield MF, Jetton TL, Labosky PA, Ray M, Stein RW, Magnuson MA, et al. PDX-1 is required for pancreatic outgrowth and differentiation of the rostral duodenum. Development. 1996;122(3):983-95.

4. Miller CP, McGehee RE, Jr., Habener JF. IDX-1: a new homeodomain transcription factor expressed in rat pancreatic islets and duodenum that transactivates the somatostatin gene. EMBO J. 1994;13(5):1145-56.

5. Ohlsson H, Karlsson K, Edlund T. IPF1, a homeodomain-containing transactivator of the insulin gene. ЕМBO J.1993;12(11):4251-9.

6. Ahlgren U, Jonsson J, Edlund $\mathrm{H}$. The morphogenesis of the pancreatic mesenchyme is uncoupled from that of the pancreatic epithelium in IPF1/PDX1-deficient mice. Development. 1996;122(5):1409-16.

7. Richardson H, Campbell SC, Smith SA, Macfarlane WM. Effects of rosiglitazone and metformin on pancreatic beta cell gene expression. Diabetologia. 2006;49(4):685-96. 